\title{
considering subject positions with biesta
}

riku välitalo ${ }^{1}$

oulu university, finland

\section{abstract}

People who attended the ICPIC conference last summer were given a opportunity to consider some perspectives offered by the acknowledged scholar and educational thinker, Gert Biesta. His presentation in Madrid focused on exploring the educational significance of doing philosophy with children from a particular viewpoint. Biesta addressed the question of whether Philosophy for Children (P4C) movement can offer something more than a clear head, that is, a critical, creative, caring and collaborative thinker. To get the message through, he analysed some wider patterns in the educational field, namely the rise of the language of learning in various educational environments. According to Biesta, this shift has created tendencies towards egocentrism in education. He articulated a subject position from which we can also start addressing the heart and soul of others. In what follows, I will explore this different take on positioning students basing on my reading of the scholarship of $\mathrm{P} 4 \mathrm{C}$ and the talk of Gert Biesta accompanied with reading of his other works. I will offer a few views that seem to entail connections between the scholarship in P4C and Biesta. Furthermore, I will pose some questions the talk provoked.

keywords: philosophy for children; subjectivity; gert biesta; community of philosophical inquiry; education.

\section{considerando as posições de sujeito com biesta}

resumo

As pessoas que participaram da conferência ICPIC no último verão tiveram a oportunidade de considerar algumas perspectivas oferecidas pelo renomado pesquisador e pensador educacional Gert Biesta. Sua apresentação em Madri focalizou-se em explorar o significado educacional de se fazer filosofia com crianças a partir de um ponto de vista particular. Biesta tratou da questão sobre se o movimento da Filosofia para Crianças pode oferecer algo a mais do que uma cabeça esclarecida, ou seja, um pensador crítico, criativo, atencioso e colaborativo. Para passar a mensagem, ele analisou alguns padrões mais amplos no campo educacional, como o surgimento da linguagem de aprendizado em vários meios educacionais. De acordo com Biesta, essa mudança criou tendências convergindo para um egocentrismo na educação. Ele articulou uma posição de sujeito a partir da qual nós podemos começar a tentar atingir o coração e a alma dos outros. No que se segue, eu explorarei esta diferente concepção de posicionar estudantes baseado na minha leitura nos estudos de Filosofia para Crianças e na fala de Gert

\footnotetext{
${ }^{1}$ E-mail: riku.valitalo@gmail.com
} 
Biesta, acompanhada de minhas leituras de seus outros trabalhos. Oferecerei algumas visões que parecem implicar conexões entre os estudos em Filosofia Para Crianças e Biesta. Além disso, colocarei algumas questões que a fala provocou.

palavras-chave: filosofia para crianças; subjetividade; gert biesta; comunidade de investigação filosófica; educação.

\section{considerando las posiciones del sujeto con biesta}

resumen

Las personas que participaron del último congreso del ICPIC tuvieron la oportunidad de considerar algunas perspectivas ofrecidas por el renombrado investigador y pensador de la educación Gert Biesta. Su presentación en Madrid se focalizó en explorar el significdo educacional de hacer filosofía con niños a partir de un punto de vista particular. Biesta trató la cuestión sobre si el movimiento de Filosofía con niños puede ofrecer algo más que una cabeza ilustrada, o sea, un pensador crítico, creativo, atencioso y colaborativo. Para mostrar su punto, el analizó algunos patrones más amplios en el campo educacional, como el surgimiento del lenguaje de aprendizaje en varios medios educacionales. De acuerdo con Biesta, este cambio creó tendencias que convergieron en un egocentrismo en la educación. Él articuló una posición del sujeto a partir de la cual nosotros podemos intentar alcanzar el corazón y el alma de los otros. En lo que sigue exploraré esta concepción diferente de posicionar los estudiantes basado en mi lectura de los estudios sobre Filosofía para Niños y en la charla de Biesta, acompañada de mi lectura de sus otros trabajos. Ofreceré algunas visiones que parecen implicar conexiones entre | Filosofía para Niños y Biesta. Más allá de ello expondré algunas consideraciones que me provocó la charla de Biesta

palabras clave: filosofia para niños; subjetividad; gert biesta; comunidad de indagación filosófica; educación. 
considering subject positions with biesta

\section{introduction}

People who attended the ICPIC conference last summer were given the opportunity to consider some perspectives offered by the acknowledged scholar and educational thinker, Gert Biesta. His presentation in Madrid focused on exploring the educational significance of $\mathrm{P} 4 \mathrm{C}$ from a particular viewpoint. Biesta started his speech by putting into question the (quite) generally accepted educational aim of $\mathrm{P} 4 \mathrm{C}$, which is developing thinking skills. ${ }^{2}$ Biesta did not argue that this well-articulated aim is something to be avoided or put aside, but he did ask whether it is enough-that is, whether it is possible to go further. In what follows, I will explain how I received his message of going further, and whether we can find views inside P4C that have addressed similar questions. Lastly, I will formulate some questions that, from my perspective, are of interest.

Biesta grounded his concern of emphasizing only thinking about his own experiences of observing P4C. The encounters he had experienced were quite verbal and conceptual, and less experiential. He also referred to the conference webpages, where people with "common interest in the development of high order, multidimensional or complex thinking" were invited to meet and discuss about their theoretical and practical views. ${ }^{3}$ The main point for Biesta was that in practice $\mathrm{P} 4 \mathrm{C}$ seems to emphasize analytical philosophy at the cost of the phenomenological or existential tradition of philosophical thought. As the title of his presentation (Touching the Soul? Education, Philosophy and Children in an Age of Instrumentalism) suggested, he was questioning whether P4C, understood as a thinking skills program, can touch the heart and soul of the student or the child.

\footnotetext{
${ }^{2}$ The thinking skills that are promoted in P4C were first elaborated by Lipman and Sharp, who started with critical and creative thinking and added caring thinking later on. SAPERE, the educational foundation promoting philosophy in schools and communities in England, added a collaborative dimension into the typology of thinking.

3 Available online at: http://congresos.fuam.es/fuamcongresos/philosophical-inquiry-withchildren-coming-of-age-family-resemblances-xviii-international-conference-of-icpic/home.

Accessed 24.7.2017.
} 


\section{a student as the origin of signification}

The question Biesta was raising concerned the positioning of the student as a subject in philosophical inquiries as it is practiced the way Biesta had observed. To get the message through, he analysed some wider patterns in the educational field, namely the rise of the language of learning in various educational environments (see BIESTA, 2006, 2010). According to Biesta, the language of learning can be seen, for example, in the growing tendency to talk about learners instead of students, or to talk about facilitators instead of teachers. The problem Biesta sees with learning is that it is unhelpful as an educational language because it is a process word and cannot address educational questions of content, purpose and relationships. According to Biesta, this shift has created a breeding ground for a subject that is the origin of signification. To illustrate his point, he talked about robot vacuum cleaners that are like intelligent adaptive systems. They learn the arrangement of tables and chairs and, in doing so, become more efficient in their vacuuming. This was to show how the language of learning works for subjects who can adapt in different environments by generating an "I who makes sense of the world and tries to comprehend the world, but does not confront the question of living in the world and with the world surrounded by otherness". Biesta wanted the P4C community to think carefully how it positions the child in the world and in relation to the world.

If $\mathrm{P} 4 \mathrm{C}$ is seen as a student-centred pedagogy in which the facilitator is only helping the student to think, and the learner could be seen positioned as an "I who raises the questions"; there is a danger that the whole process serves only the desires of the learner to use the terms Biesta accompanied in his presentation. This can position the child or the student as a consumer who only seeks opportunities to satisfy his/her desires or needs in various settings (see BIESTA 2013). Communities of philosophical enquiries (CPIs) become places that are there to serve their customers and help to meet the customers' needs. As I understood what Biesta was saying, this could lead to something that he was metaphorically 
referring to as world-destruction. If this was Biesta's concern, then one possible counterargument that is worth mentioning, relates to the communal aspect of CPI.

Although the concept of learning is individualizing, as in the end we can learn only by ourselves, P4C literature has stressed from the very beginning the communal aspect of learning. Lipman (2003) described a CPI as a self-correcting system, meaning that by being critical the participants steer the course of an inquiry. So, a more adequate way to describe the pedagogy could be dialoguefocused or inquiry-centred than student-centred. It could also be said that the desires of individuals are corrected in a way that moves the community or collective from what is desired towards what is desirable. The egocentrism that Biesta was concerned about in $\mathrm{P} 4 \mathrm{C}$ is confronted with the collective process of truth-seeking and meaning-making. For example, Sharp's (2007) articulation of a CPI as an activity that "fosters an ability to put one's ego in perspective" illuminates this internalized ability that grows out of the dialogue towards "a slow realization of what it is to be human and live the human predicament" (SHARP, (2007, p. 5). This distinctive aspect is related to the philosophical "meta" nature of a CPI. It is a practice beyond practices in the way it tackles the questions imbedded in various communities and practices including itself.

Still, I think Biesta's concern is worth paying attention to, although I see another risk that Biesta was raising maybe less explicitly: if, by focusing on thinking, P4C is adapting an instrumental use of philosophy. By this I mean that $\mathrm{P} 4 \mathrm{C}$ positions a child in the world as someone who needs to be filled with certain skills and competencies to survive in the 21th century. In other words, by emphasizing analytical reason and a particular ideal of thinking, P4C runs the risk of positioning the student as someone in need of being subjected to rather than subject in. Research has already been done to address this very issue. Similar concerns have been raised, for example, by Kohan (2002), Vansieleghem (2005) and Biesta himself (2011).

Although I personally see both concerns as worth considering in practice, I will concentrate on the former case of positioning the student as the origin of 
signification, as that seemed to be the concern Biesta wanted to address. Basing on my own reading of $\mathrm{P} 4 \mathrm{C}$ literature, the question of how $\mathrm{P} 4 \mathrm{C}$ positions the child in the world, in relation to the world and in relation to herself/himself is also addressed in the field; we can find some interesting takes on this very issue. For example, Walter Kohan, Karin Murris and David Kennedy have made efforts to study different aspects of childhood and the ways educators should pay attention to the emergence of subjectivity (see VÄLITALO et al. 2016). As I see it, this work resonates with Biesta's concern. From now on, I refer to this concern with a concept of subjectification ${ }^{4}$, which Biesta has used in his other works to talk about one important function or a domain of education, and which I think can be used here.

\section{subjectification in the event}

Roughly put, the domain of subjectification focuses our attention on the ways of freeing students from established orders and constraints and allowing an appearance of the child as an individual (BIESTA, 2012; 2010, chap. 1). The event of appearing as an individual manifests only in relation to others and is therefore necessarily bounded to the actions of others. So, in this sense, subjectivity is more like an event than a property or essence, and necessarily requires difference and plurality (MURRIS, 2016, p. 24; BIESTA, 2010, p. 21). In this way perceived, subjectivity can neither be a product nor an outcome of our educational efforts, and in the end the teacher can only hope for the best. This does not mean there is nothing to do in terms of subjectification. For example, Karin Murris (2016, p. 26) drawing from Biesta, sees that to acknowledge this domain of education, the teacher should first occupy him/herself with questions like what a child can be expected to achieve in terms of, for example, morality and reasoning, but not about what a child is or should become. Moreover, Biesta (2010) sees that the teacher can give opportunities for such events, although not produce them. This was one of the main points in his speech as he was discussing encounters with

\footnotetext{
${ }^{4}$ In his later works, he has also referred to this domain as subjectness.
} 
plants and animals, which require patience, attention and care, but where "higherorder" thinking is irrelevant.

So what role might philosophy have in giving this opportunity? How P4C can address Biesta's call for coming to exist in the world and with the world as subject, without putting itself in the centre of the world? One important observation on my part was that it moves our attention from "what" will emerge to "who" will emerge in a CPI. In Beyond Learning, Biesta talks about communities of those who have nothing in common (BIESTA, 2006, chp. 3). He distinguishes this from what he calls a rational community drawing partly from Lingis (1994). In the rational community, what is being said matters, and the insights offered can be put to universal categories in a way that these utterances are detached from the one who first formulated them. Membership in a rational community creates rational agents, that is, as members start to master the common discourse. This sounds very reasonable, especially from a "common sense educational" point of view. As teachers and P4C practitioners, this is what we mostly do - try to free our students from the dependency of our guidance. Instead, Biesta asks us to consider a subjectivity that has nothing to do with the rational community; it is quite opposite. He wants us to see our students as free already from the very beginning, capable to add something into our common existence. This is not possible if we try identify their words and deeds using already existing ways of speaking, but in paying attention to and to giving equal possibility to the "noise" that springs from these strangers (in this case, the children), and that can turn into a voice once someone is ready to hear it and respond. I believe Kennedy (2014) ${ }^{5}$ is developing a very similar idea in his demand to move beyond epistemological "egocentrism", or Kohan (2014) who urges us to prepare for a different form of reason, a different theory of knowledge and a different ethic. Kennedy (2010) also talks about the nature of dialogue as an interplay of not only ideas: "boundaries are continually being reconfigured - not just conceptual boundaries, but intersubjective and social

\footnotetext{
5 Although Kennedy uses the term "intersubject", which he defines as an "emergent form of subjectivity in our time which reconstructs its borders to include the other, and which understands itself as always building and being built through a combination of internal and external dialogue." (Kennedy 2004, p. 201)
} 
ones as well. There is no such thing as just a dialogue of ideas" (KENNEDY, 2010, p. 42). This, I believe, was also Biesta's point: not to live in an idea of the world, but in the world. To do this as adults, we need to ask what the child or the student is asking of us (as the plant and the animal).

Addressing this question, Kennedy and Kohan (2017) talk about refusing the idea of the transformation of childhood into adulthood as a primary pedagogical project. They (KENNEDY; KOHAN, 2017) see that education should be a process that "fosters, nurtures, cares for and or restores the experience of childhood itself" (p. 50). I believe the notion resonates well with the concern Biesta is raising, and Kennedy and Kohan have elaborated on this issue in many of their publications (see, for example, KENNEDY 2010, 2006; KOHAN 2012, 2015). For example, Kennedy sees philosophy to be the epistemic and curricular wedge to open the experience of childhood to reflection on the parts of children and of adults (KENNEDY, 2010). But for this to be the case, we need to be ready to articulate philosophy not only as interplay of ideas, but also as an experience that moves us on another level or dimension.

\section{a pedagogy of subjectification}

Basing on my reading of $\mathrm{P} 4 \mathrm{C}$, Biesta's concern interestingly connects with the literature in P4C and can develop further and inspire the existing undertakings in P4C. The connections between some scholars inside P4C and Biesta show that Biesta's work can have a lot to offer to P4C, especially in its focus on the educational significance of doing philosophy for/with children. One interesting issue with regards to the scholarship inside $\mathrm{P} 4 \mathrm{C}$, concerns the educational work that Biesta shortly touched in his presentation. Biesta articulated the educational work as entailing interruption, suspension and sustenance. I would be interested to hear more about this, particularly the interruption of desires in relation to philosophical work with children. As I mentioned previously, Lipman (2003) described a CPI as relying on self-correction (the critical dimension of CPI), and it is quite widely accepted as a basic theoretical assumption in P4C. While talking about robot vacuum cleaners as a metaphor for criticizing pragmatism, Biesta 
noted how they cannot ask whether the environment they are adapting in is an environment worth adapting to. The educational work, Biesta emphasized regarding this issue, relates to "holding" students in the middle ground between world-destruction and self-destruction. It would be interesting to hear further thoughts on the teacher's role in this task. Furthermore, as Biesta's latest book is called the Rediscovery of Teaching, a book I unfortunately have not had a chance to read yet, I wonder how Biesta sees the appearance of the teacher-subject. In other words, what would be teaching as an expression of the person who teaches?

\section{final thoughts}

Lastly, related to the previous questions, it would be interesting to see what this means in practice. A critique directed towards some P4C scholars mentioned here is that they are lacking ideas about what it means to apply their thinking in practice (see WHITE, 2012). On my behalf, as a teacher who has mainly worked in classrooms for the past ten years, I would say that for me this is philosophy for teachers or educators, or a philosophy of teaching. As such, it does not necessarily need to entail any applications to conduct a philosophical dialogue with children or students. Working with the ideas presented here for many years has motivated me to try to see and hear the child and the other creatures of the world as equal members of our common existence. It has triggered a self-study that mainly focuses on my work with future generations, but also expands my horizon in a more general sense of how to come together in "wordly" places.

\section{references}

BIESTA, Gert. The Beautiful Risk of Education. London: Paradigm Publishers, 2013.

BIESTA, Gert. Giving Teaching Back to Education. Phenomenology \& Practice 6, n. 2:35-49, 2012.

BIESTA, Gert. Philosophy, Exposure, and Children: How to Resist the Instrumentalisation of Philosophy in Education. Journal of Philosophy of Education 45, n. 2:305-319, 2011.

BIESTA, Gert. Good education in an age of measurement. Boulder, CO: Paradigm Publ, 2010. BIESTA, Gert. Beyond Learning. Boulder: Paradigm Publishers, 2006.

GOLDING, Clinton. We Made Progress: Collective Epistemic Progress in Dialogue without Consensus. Journal of Philosophy of Education 47, n. 3:423-440, 2013.

KENNEDY, David. Neoteny, Dialogic Education and an Emergent Psychoculture: Notes on Theory and Practice. Journal of Philosophy of Education 48, n. 1:100-117, 2014. 
KENNEDY, David. Philosophical Dialogue with Children : Essays on Theory and Practice. Lewinston: Edwin Mellen Press, 2010.

KENNEDY, David. Communal Philosophical Dialogue and the Intersubject. International Journal of Applied Philosophy18, n. 2:201-216, 2004.

KENNEDY, David; KOHAN, Walter. Childhood, education and philosophy: a matter of time. In The Routledge Handbook of Philosophy for Children, edited by Maughn Gregory, Joanna Haynes and Karin Murris. New York: Routledge, 2017, p. 46-52.

KOHAN, Walter. Childhood, Education and Philosophy: New Ideas for an Old

Relationship. New York: Routledge, 2015.

KOHAN, Walter. Philosophy and childhood: Critical Perspectives and Affirmative

Practices. New York: Palgrave Pivot, 2014.

KOHAN, Walter. Education, Philosophy And Childhood: The Need to Think an

Encounter. Thinking: The Journal of Philosophy for Children 16, n. 1:4-11, 2002.

LINGIS, Alphonso. The Community of Those Who Have Nothing in Common. Colorado:

Paradigm Publishers, 1994.

LIPMAN, Matthew. Thinking in education. 2nd ed. Cambridge: Cambridge University Press, 2003.

MURRIS, Karin. The Posthuman Child. London \& New York: Taylor \& Francis Group, 2016. SHARP, Ann M. The Classroom Community of Inquiry as Ritual: How we can Cultivate Wisdom. Critical and Creative Thinking 15, no. 1:3-14, 2007.

VÄLITALO, Riku; JUUSO, Hannu; SUTINEN, Ari. Philosophy for Children as an Educational Practice. Studies in Philosophy and Education 35, no. 1:79-92, 2016.

VANSIELEGHEM, Nancy. Philosophy for Children as the Wind of Thinking. Journal of Philosophy of Education 39, no. 1:19-35, 2005.

WHITE, John. Philosophy in Primary Schools? Journal of Philosophy of Education 46, n. 3: 449-460, 2012.

received in: 04.08.2017

accepted in: 28.08.2017 